\title{
Impact of the Main Leadership Style and Teachers' Job Dedication on Teacher Professionalism
}

\author{
Moh. Muhdor ${ }^{* *}$, Nur Ahyani², Syaiful Eddy ${ }^{2}$ \\ ${ }^{1}$ MTs Miftahul Huda Cinta Karya, Indonesia \\ ${ }^{2}$ Universitas PGRI, Palembang, Indonesia \\ *Corresponding author. Email: mohmuhdor821722046@gmail.com
}

\begin{abstract}
The goal of this review is to evaluate and examine the impact of the Headmaster's Style Of leadership, Teacher's Job Dedication on the Professionalism of Teachers in Madrasah Tsnawiyah Equals in the Plakat Tinggi District. This type of study is quantitatively descriptive. The sample in the study consisted of 102 respondents with survey instruments in the form of a survey (questionnaire). The findings indicate that: 1) there is a big impact of the headmaster's style of leadership on teacher professionalism; 2) there is a serious impact of the teacher's commitment to teaching professionalism, and 3) there is a strong impact between the principal's style of leadership and the teacher's commitment to teaching professionalism.
\end{abstract}

Keywords: Main Leadership Style, Teachers' Job Dedication, Teacher Professionalism

\section{INTRODUCTION}

The presence of a leader in an organization is required, since the leader will decide the direction the organization will take. Leadership itself is the action of an individual to control and motivate all participants to achieve predetermined goals. Leadership is known to be the ability to transfer and control people [1]. The principal of the school is the pioneer of educational institutions. The Headmaster must be able to mobilize all representatives of the school to achieve educational objectives. Conceptually, the principal responsible for the delivery of education is the principal of the school. The head of the school must be responsible for the micro-management of education, namely the stage at which the teaching and learning process is addressed and introduced, and the teacher must be the main director of education. That is in line with the opinion of Mulyasa [2] that the teacher is the most influential factor in developing quality education processes and results.

The position of the principal as a leader with a style of leadership must be able to influence other people or employees [3]. The style of leadership implemented by the Principal would have an effect on the process of creating comfort, order in the learning process, in particular on the engagement of teachers to work and the professionalism of teachers. In managing school organizations, the Principal demonstrates a style or behavioral pattern to direct and influence the actions of others, so that the Principal may use multiple types of leadership that are compatible with the environment, characteristics or culture of the school organization itself. The attributes of the school as an educational institution would have an influence on the efficacy of the style of leadership applied. Modern schooling carries the fate of accountability for destructive developments in the moral and spiritual domain of humanity [4]. The attitude of the principal who has no authority, is indecisive and acts indifferently towards the subordinates, will create an environment of an unpleasant educational climate, and the learning process will run accordingly. In the meantime, the conduct of the principal, who is authoritative, assertive, reasonable and attentive to subordinates or teachers and students, would create a harmonious and relaxed learning environment and, indeed, an educational achievement. In a more optimistic context, leadership models should be applied in a directive that is supportive and participatory. These three types of leadership can be implemented fairly and concurrently in the leadership process. A balanced portion of these types of leadership would promote the advancement of teacher professionalism.

Every Headmaster has a different style of leadership, and there is no one who is the strongest or most successful style of leadership, since it all depends on the situation and circumstance of each subordinate. As 
described in Suharsaputra [5] which indicates that a leader can accomplish goals in a variety of ways and styles, depending on the internal circumstances and external challenges that face him, so that successful leadership cannot be related to only certain aspects of the leader or environmental conditions that surround him. Wahjosumidjo [6] stressed that leadership can be divided into four approaches, namely: first a psychological approach; second, a situational approach; third, a behavioral approach; and fourth, a contingency approach.

Headmaster leadership can occur when the principal communicates with others, such as holding private discussions with teachers, peers, and students [7]. The characteristics of leadership shown by the Theory are impartial, egalitarian, polite, humorous, truthful, diligent, assertive, capable of managing emotions, respect, inspiration, equal, strong and religious attitudes towards all members. The leadership of the principal is prophetic leadership. The Principal should be capable of carrying out inventions, be able to direct all stakeholders and the school as an education institution [8].

Even so, the leader also seems to be a figure who does not discriminate from one another. The Headmaster is a leader who is egalitarian, impartial, polite, funny, who does not enforce his will, who is capable of positioning himself and who is capable of treating subordinates according to the person of his subordinate. The key role of the Headmaster as a leader in education is to build a teaching and learning situation so that teachers can teach and students can learn well, and the ability of the Principal to lead the school is very influential in raising the dedication of teachers to work, as well as in improving and developing an efficient (effective) learning process. And right at the goal.

Previous research of Damayani et al [9] clarified that leadership goals generate compliance from those who are guided, but that obedience has different reasons for someone to obey the leader because they escape the repercussions of disobedience, obey because their social needs are met, and obey because the values in the leader are acceptable. Values that have been internalized. Hard work done with support or motivation would give the instructor a special satisfaction in doing his job. Employees who are pleased with the work they have done would be inspired to increase efficiency in order to have an effect on increasing the success of the company. Employees who work peacefully and without coercion will achieve successful results and support the employee's organizational contribution to the business.

Findings of the preliminary observations, it was found that the leadership style of Madrasah Tsanawiyah Miftahul Huda Cinta Karya and Muallimin Islamiyah and Madrasah Tsanawiyah is comparable to the leadership style of the headmaster: (a) the everyday action of the Leader is responsive, open, cheerful, assertive, prudent, disciplined and dedicated and has a healthy emotion; (b) the assignment of tasks is carried out equally and offers direction; (c) joint decisionmaking/consensus; (d) oversight through direct monitoring of progress; (e) school growth involves the development of school facilities; (f) open and two-way contact using a simple and easy-to-understand language, and $\mathrm{g}$ ) encouragement to provide affirmation and to meet the needs of all staff, but there are still teachers who are not dedicated to the mission, as can be seen from findings made by researchers during the 3 months of October, November, December 2020, from attendance by teachers who are always late to teach, which, if this continues, will reduce the work of teachers.

The dedication of the teacher to work is a genuine attempt of the instructor to stay compliant with the mission. The teacher's role is so great that it should be carried out in good quality to achieve educational objectives. The job performed by the teacher would be carried out well if there is a strong commitment in the teacher to carry out each task. In addition, dedication is a concept that must be possessed by a person who is a teacher, and commitment is an arrangement between a person and himself to carry out a duty in full sense of obligation, care and loyalty.

Educators who have a high degree of dedication are those who have a sense of concern, a sense of duty and a sense of loyalty to their key duties, who feel supported in their job. Teacher engagement is also assessed by indicators: concern, obligation and loyalty. Suitable teaching can also achieve maximum leaners [10]. Caring, the consideration for their duties is one of the attributes of an instructor who has a strong sense of concern. Sahertian [11] notes that "concern can arise if there is a sense of love for the task and profession that one is involved in" a person should feel proud of his profession, no matter how many difficulties he faces in carrying out his duties.

On the basis of this definition, the authors consider it necessary to carry out further research on teacher performance under the title "Impact of the Main Leadership Style and Teachers' Job Dedication on Teacher Professionalism"

\section{METHODS}

According to Sukmadinata [12], the experimental report is a compilation of techniques or practices for conducting research based on basic assumptions, philosophic and ideological views, questions and issues at hand. The study design has a particular design for research. This study design is quantitative research by explaining the outcomes of the experiment.

Quantitative analysis is based on the theory of positivism, which emphasizes empirical phenomena and 
is quantitatively studied. The sample in this study was Madrasah Tsanawiyah Equal in the Plakat Tinggi District, which was sampled in this study using objective sampling, that is to say, teachers who were used as research samples were teachers in each elementary school with a total of 102 teachers. Techniques are required for the data gathering, both techniques for the provision of data and techniques for the classification of data that have been collected. The same argument was made by [9] that the method of collecting data is a method used to collect data, while the information collection methodology is the method used to carry out the method chosen, which uses survey information and analysis.

\section{RESULTS AND DISCUSSION}

After testing the analytics criteria, namely the normality test and the homogeneity test, the hypothesis test was continued. After the data are declared to have met the criteria to be checked, the model is formulated using the t-test and the F-test to assess the effect on the variables to be tested in part and at the same time.

\section{The First Hypothesis Test $\left(\mathrm{H}_{1}\right)$}

Table 1. Results of the $t$-test study for variable $\left(\mathrm{X}_{1}\right)$ on $\mathrm{Y}$

Coefficients $^{\mathrm{a}}$

\begin{tabular}{|c|c|c|c|c|c|}
\hline \multirow[b]{2}{*}{ Model } & \multicolumn{2}{|c|}{$\begin{array}{l}\text { Unstandardized } \\
\text { Coefficients }\end{array}$} & \multirow{2}{*}{$\begin{array}{c}\text { Standardized } \\
\text { Coefficients }\end{array}$} & & \\
\hline & B & Std. Error & & $\mathrm{t}$ & Sig. \\
\hline $\begin{array}{c}\text { (Constant) } \\
\text { Headmaster Leadership } \\
\text { Style }\left(\mathrm{X}_{1}\right)\end{array}$ & $\begin{array}{c}29.583 \\
.189\end{array}$ & $\begin{array}{c}12.560 \\
.078\end{array}$ & .225 & $\begin{array}{l}2.355 \\
2.440\end{array} \mid$ & $\begin{array}{l}.020 \\
.016\end{array}$ \\
\hline
\end{tabular}

a. Dependent Variable: Teacher Professionalism (Y)

Find out the impact of the above estimation of the $t$ test, the significance value is considered to be 0.016 . Since the critical level (probability) is less than $0.05, \mathrm{H} 0$ is rejected. This means that $\mathrm{Ha}$ is approved, so the output of the principal has the effect of $\mathrm{X}_{1}$ on $\mathrm{Y}$ of 0.016
$<0.05$ and the $\mathrm{t}$ value is $2.440>\mathrm{t}$ table 1.665 , so that it can be inferred that Ha 1 is approved, which means that there is a substantial impact between $\mathrm{X}_{1}$ and $\mathrm{Y}$.

\section{The Second Hypothesis Test (H2)}

Table2. Results of the t-test study for variable $\left(\mathrm{X}_{2}\right)$ on $\mathrm{Y}$.

Coefficients $^{\mathrm{a}}$

\begin{tabular}{|l|r|r|c|c|c|}
\hline \multirow{2}{*}{ Model } & \multicolumn{2}{|c|}{ Unstandardized Coefficients } & Standardized Coefficients & \multicolumn{2}{|c|}{} \\
\cline { 2 - 6 } & \multicolumn{1}{c|}{$\mathrm{B}$} & Std. Error & Beta & $\mathrm{t}$ & Sig. \\
\hline 1 (Constant) & 29.583 & 12.560 & & 2.355 & .020 \\
Job Dedication (X2) & .508 & .129 & .363 & 3.940 & .000 \\
\hline
\end{tabular}

a. Dependent Variable: Teacher Professionalism (Y)

3. The Third Hypothesis Test (H3)

Table 3. Results of the F Test Analysis

ANOVA ${ }^{b}$

\begin{tabular}{|l|c|c|c|c|c|}
\hline Model & Sum of Squares & df & Mean Square & F & Sig. \\
\hline 1 Regression & 2193.040 & 2 & 1096.520 & 14.736 & $.000^{\mathrm{a}}$ \\
Residual & 7366.773 & 99 & 74.412 & & \\
Total & 9559.814 & 101 & & & \\
\hline
\end{tabular}

a. Predictors: (Constant), Headmaster Leadership Style $\left(\mathrm{X}_{1}\right),($ Constant $)$, Job Dedication $\left(\mathrm{X}_{2}\right)$

b. Dependent Variable: Teacher Professionalism (Y)

Focused on the above, it is understood that the value of significance for the effect of $\mathrm{X}_{1}$ and $\mathrm{X}_{2}$ on $\mathrm{Y}$ at the same time or together is $0.000<0.005$ and the value of $F$ counts 14.736> F table 3.09 so that it can be inferred that the value of $\mathrm{F}$ counts 3 is Ha 3 approved, which 
means that $\mathrm{X}_{1}$ and $\mathrm{X}_{2}$ have a strong influence on $\mathrm{Y}$ at the same time.

Depending on the outcomes of the analysis of research data described in SPSS version 22. Well before research was conducted out, the data criteria were first tested, namely the validity test and the reliability test. The data validity test was carried out using the validation test carried out with the validator, namely the PGRI Palembang University lecturer. Then proceed to verify the validity of the analysis using the SPSS software version 22 estimate. The findings of this study validity measurement for the leadership style variables of the main note are all correct so that the statement items can be further checked. The results of the study validity measurement for the teacher's job commitment variable note that all of them are accurate so that the statement items can be further checked. The results of the validation analysis calculation for the vector instructor professionalism show that all of them are correct so that the statement items can be further checked. The pre-requisite data test would then be continued for the reliability test. After calculation, it is known that the key leadership style variable had a value greater than the $\mathrm{r}$ table, that the teacher's dedication variable was greater than the $\mathrm{R}$ table, and that the teacher's professionalism variable had a value greater than the $\mathrm{r}$ table, so that it could be concluded that all the study variables had been considered accurate.

\section{CONCLUSION}

Published the results of the studies that have been conducted, it can be inferred that the leadership style of the Principal has an impact on teacher competence depending on the outcomes of the t-test study. This indicates that there is an effect of a Headmaster's style of leadership on the professionalism of the Madrasah Tsnawiyah Equivalent Teachers in the Plakat Tinggi District, who referred to the first hypothesis. Teacher's dedication to work has an impact on teacher professionalism based on the findings of the t-test study. It reveals that there is an impact of teacher job dedication on teacher professionalism at Madrasah Tsnawiyah Equivalent in Plakat Tinggi District has responded to the second hypothesis. Principal Leadership Style and Teacher Job Engagement have a common impact on Teacher Professionalism based on the findings of the F-test study. This shows that the Principal Leadership Style and Teacher Work Dedication jointly affect the Professionalism of Teachers in Madrasah Tsnawiyah Equivalent in the Tinggi Plakat District has responded to the third hypothesis.

\section{AUTHORS' CONTRIBUTION}

Moh. Muhdor: designed and performed experiments and analysed data. Nur Ahyani and Syaiful Eddy: Correcting and proofing.

\section{ACKNOWLEDGMENTS}

Thank you to your family and colleagues, the Chancellor of the PGRI Palembang University, the Director of the PGRI Palembang University Postgraduate Program, the Chair of the PGRI Palembang University Education Management Masters Program and the supervisors who have contributed to the completion of this study journal.

\section{REFERENCES}

[1] Zainal \& Ramly. (2014). Kepemimpinan dan Perilaku Organisasi [Leadership and Organizational Behavior]. Jakarta: PT Rajagrafindo Persada.

[2] Mulyasa. 2011. Manajemen \& Kepemimpinan Kepala Sekolah [Principal Management \& Leadership]. Jakarta: PT. Bandung Rosyda Karya.

[3] Asvio, N., Yamin, M., \& Risnita. (2019). Influence of Leadership Style, Emotional Intelligence and Job Satisfaction toward Organizational Commitment (Survey at SMA Muhammadiyah South Sumatera). International Journal of Scientific \& Technology Research 8 (8).

[4] Maseleno, A., Ayshwary, B., Ivanova, T. N., Hashim, W., Nguyen, P. T., Shankar, K., Kristiawan, M., Huda, M. (2019). General Theoretical and Philosophical Aspects of Modern Education. Aspectos Teóricos y Filosóficos Generales de la Educación Moderna. Revista San Gregorio 2019, No. 32 Special Issues August.

[5] Suharsaputra. (2016). Kepemimpinan Inovasi Pendidikan: Mengembangkan Spirit Enterpreneurship Menuju Learning School [Educational Innovation Leadership: Developing a Spirit of Entrepreneurship Towards a Learning School]. Bandung: PT Refika Aditama.

[6] Wahjosumidjo. (2013). Kepemimpinan Kepala Sekolah: Tinjauan Teoretik dan Permasalahannya [Leadership of Principals: Overview of Theory and Problems]. Jakarta: PT Rajagrafindo Persada.

[7] Hafizoh., Harapan, E \& Destiniar (2020). Pengaruh Profesionalisme Guru Dan Supervisi Kepala Sekolah Terhadap Kinerja Guru [Effect of Teacher Professionalism and Principal Supervision on Teacher Performance]. Jurnal Manajemen, 
Kepemimpinan, dan Supervisi Pendidikan.Volume 5, No. 2, Juli-Desember.

[8] Andriani, S., Kesumawati, N., \& Kristiawan, M. (2018). The Influence of the Transformational Leadership and Work Motivation on Teachers Performance. International Journal of Scientific \& Technology Research, 7(7).

[9] Damayani, Titin., Arafat, Y. dan Eddy, S. (2020). Pengaruh Kepemimpinan Kepala Sekolah dan Motivasi Kerja terhadap Kinerja Guru [The Influence of Principal Leadership and Work Motivation on Teacher Performance]. Journal of Innovation in Teaching and Instructional Media Vol. 1 No. 1, Page:46-57.

[10] Hanim, H., \& Rahmadoni, J. (2020). Determination of Lecturer Reception Using Analytical Hierarchy Process (AHP). Journal of Applied Engineering and Technological Science (JAETS), 1 (2), 136141.

[11] Sahertian, P. A. (2014). Profil Pendidik Profesional [Profile of Professional Educators]. Jakarta:Andi Offset.

[12] Sukmadinata, N. S. (2015). Metode Penelitian Pendidikan [Educational Research Methods]. Bandung: Remaja Rosdakarya. 